NBER WORKING PAPER SERIES

\title{
PRODUCTION TECHNOLOGY DIFFERENCES BETWEEN CANADIAN-OWNED AND FOREIGN-OWNED FIRMS USING TRANSLOG-PRODUCTION FUNCTIONS
}

Vittorio Corbo

Oli Havrylyshyn

Working Paper No. 981

\section{NATIONAL BUREAU OF ECONOMIC RESEARCH 1050 Massachusetts Avenue Cambridge MA 02138}

September 1982

Work for this study was done under the NBER study of Multinational Firms and Host-Country Technology directed by Irving B. Kravis and Robert E. Lipsey, and financed under Grant No. PRA-7726359 from the National Science Foundation. It is part of the NBER's research program in International Studies. We are indebted to John McVey and Statistics Canada for the data on foreign-owned firms as well as the preparation of the regression analyses. Any opinions expressed are those of the authors and do not necessarily represent those of the National Bureau of Economic Research or the National Science Foundation. 
PRODUCTION TECHNOLOGY DIFFERENCES BETWEEN CANADIAN-OWNED AND FOREIGN-OWNED FIRMS USING TRANSLOG-PRODUCTION FUNCTIONS

\section{$\underline{\text { ABSTRACT }}$}

The discussion of foreign ownership in Canada frequently refers to a conventional view that foreign-owned firms are larger, more capital-intensive, pay higher wages and are more efficient. Evidence for these characterizations has unfortunately come from comparisons of partial productivity measures of labor or measures of average capital-intensity, with all the uncertainty that this entails. It is the object of this paper to compare the technology characteristics of Canadian and US-owned establishments in Canada by means of a translog production function estimate, utilizing micro level data. While we find strong evidence for the view that the two groups operate with different technologies, and that US-owned establishments are larger, we do not find support for the conventional view that US-owned establishments are more capital-intensive, have higher labor productivity, or lower costs of production.

Vittorio Corbo Pontificia Universidad Catolica

Casilla 114-D

Santiago, Chile
011 Havrylyshyn Department of Economics George Washington University Washington, D.C. 20052

(202) 676-7196 
PRODUCTION TECHNOLOGY DIFFERENCES BETWEEN CANADIAN-OWNED

AND FOREIGN-OWNED FIRMS USING TRANSLOG-PRODUCTION FUNCTIONS

\section{INTRODUCTION AND BACKGROUND}

The econometric analysis presented here has as its purpose to determine the nature of technology differences between domestic and foreign-owned firms in Canada, for a sample of eight industries. As a background to this, we first review the key issues of public discussion on foreign-ownership in Canada to provide a clearer policy perspective and to identify the principal hypotheses pertaining to technology, some of which the present analysis is able to elucidate. This is done in the rest of Part I, while in Part II the model is presented, and in Part III empirical results are given for the production function estimates, the key parameter values relating to technology differences, and for a simulation analysis which isolates the existence of technology differences as distinct from scale and factor price effects. Part IV summarizes the findings.

Like all new lands in the 19th Century, Canada depended upon foreign investment for development capital. Unlike its neighbor to the south, Canada did not over time move from the status of net capital importer to that of net capital exporter; indeed the role of foreign investment has increased substantially since 1950. This doubtless contributed to the decline in the public and political welcome accorded to foreign investment in Canada since the mid-60s, and led to such key actions as the 1972 study of the Government of Canada known as The Gray Report, and the subsequent establishment of the Foreign Investment Review Agency (FIRA) in 1974. The existence of FIRA makes Canada one 
of only three industrialized countries -- along with Australia and Japan -- having formal review mechanisms regulating entry of foreign firms, ${ }^{1}$ although this in itself by no means implies Canada is effectively less open to foreign investment than other industrial countries. The debate begun in the $1960 \mathrm{~s}$ and leading up to the governmental reviews in the Watkins Report, the Wahn Committee, the Gray Report, and finally the establishment of FIRA, ${ }^{2}$ still continues today. Thus for example, a 1977 study by T. L. Powrie of the University of Alberta concludes that the benefits to Canada of the cumulative investment from 1950 to 1976 were equal to only about six month's of average GNP growth over the period, ${ }^{3}$ though this has been disputed by others. 4 Inasmuch as the focus of our study is upon the nature of technological differences in production between domestic and foreign firms, we will not delve deeply into the debates on the various aspects of foreign investment in Canada. In this section it will be our intent only to outline briefly the policy issues found in this large literature which are most germane to technology effects.

\footnotetext{
${ }^{1}$ A. E. Safarian, "Policy on Multinational Enterprises in Developed Countries," Canadian Journal of Economics, December 1978.

${ }^{2}$ A recent review of this is found in S. Globerman (1979), U.S. Ownership of Firms in Canada, C.D. Howe Research Institute, Montreal, 1979 .

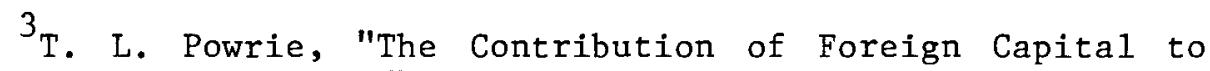
Canadian Economic Growth," mimeo, Department of Economics, University of Alberta, July 1977.

${ }^{4}$ Op. cit., Globerman.
} 


\section{1 The Determinants of Foreign Investment in Canada}

In the global context two broad lines of analysis on multinationals are found: first what are the determinants of this flow of direct investment ${ }^{5}$; secondly what is the effect of such investment upon the host country. For the flow among industrial countries in particular, the work of Vernon provides a well known summary, whereas the impact upon developing countries--which no doubt has some unique characteristics--is most recently reviewed by Lal1 and Streeten. 6

In the case of Canada, several studies have investigated the determinants of foreign investment. First, many writers, e.g. Eastman and Stykolt, ${ }^{7}$ point to tariff-walls as an incentive to invest in production in Canada, rather than sel1 from parent plants (most often in the U.S.). Secondly, others (Horst and Caves ${ }^{8}$ ) while not ignoring this effect, emphasize the competitive advantage U.S. firms

${ }^{5}$ For example, see Thomas Horst, "Firm and Industry Determinants of the Decision to Invest Abroad: An Empirical Study," Review of Economics and Statistics, 54, No. 3, August 1972, pp. $258-266$.

${ }^{6}$. Vernon, Storm Over Multinationals, Cambridge, Massachusetts: Harvard University Press 1977 and J. Lall and Paul Streeten, Foreign Investment, Transnationals and Developing Countries, Boulder: Westview Press, 1977.

7 See H.C. Eastman and S. Stykolt, The Tariff and Competition in Canada. This theme is also important in the Gray Report, and is alluded to as the cause for any "costs" foreign investment imposes by Safarian (1979), op. cit. For a broader review see Alan M. Rugman, Multinationals in Canada: Theory, Performance and Economic Impact, Boston: Martinus Nijhoff Publishing Co., 1980.

8 Thomas Horst, "The Industrial Composition of U.S. Exports and Subsidiary Sales to the Canadian Market," American Economic Review, 62, No. 1, March 1972, pp. 37-46. Richard E. Caves, "Causes of Direct Investment: Foreign Firms' Shares in Canadian and United Kingdom Manufacturing Industries," Review of Economics and Statistics, 56, No. 3, August 1979, pp. 279-293. 
possess in the form of product differentiation and R\&D. This implies that the profitability of transferring capital via direct investment is greater than via portfolio investment, or that the former is more efficient. ${ }^{9}$ This is a key point dealing with technology differences to which our study is addressed, and we return to elaborate the literature's findings below.

Third, access to resources and raw material supplies continues to be an important determinant of investment in the 20 th Century, with the predominant role of timber giving way in the inter-war period to pulp and paper and later minerals. The latter two along with petroleum became the principal resource attractions after World War II. ${ }^{10}$ Lastly, the degree of scale economies appears to be closely related to the extent of foreign investment, as concluded by the Horst and Caves studies, ${ }^{11}$ and suggested in the factual evidence of relative firm size: in general, foreign-controlled firms tend to be larger in size than domestic ones.

In summary, four factors stand out as determinants of foreign direct investment in Canada: the tariff-walls; the relative efficiency of direct over portfolio investment attributable to both

${ }^{9}$ The argument can also be found in H.G. Baumann, "Merger Theory, Property Rights, and the Pattern of U.S. Direct Investment in Canada," Weltwirtschaftliches Archiv, 3, No. 4, 1974, pp. 677-698. See also, Globerman (1979), Chapter 3.

${ }^{10}$ See Hugh J. Aitken, American Capital and Canadian Resources, Cambridge, Massachusetts: Harvard University Press, 1961.

11 These findings are confirmed in P. Gorecki, "The Determinants of Entry by Domestic and Foreign Enterprises in Canadian Manufacturing Industries: Some Comments and Empirical Results," Review of Economics and Statistics, 58, No. 4, November 1976, pp. 485-488. 
market-competition effects such as product-differentiation and value of intangible assets from $R$ \& $D$; security of access to natural resources, and fourth, the effect of scale economies.

\section{I.2. The Impact of Foreign Investment on the Canadian Economy}

Foreign investment has been analyzed as affecting the Canadian economy in the following areas: extraterritorial control of economic decisions; financial effects; product line and trade pattern effects; effects on industrial concentration and competitiveness; effects upon productivity, technology, and efficiency. It is in the last area that this study will attempt to provide new evidence, hence the other areas are discussed only briefly in this section.

On the one side, negative effects are well summarized in the principal government reports of the early seventies (the Watkins, Wahn and Gray reports, described in Rugman) which emphasized in particular the notion of extraterritoriality, that is, the possibility that production decisions of Canadian subsidiaries were made by parent offices outside Canada in a manner inimical to Canadian economic interests. In addition, they contend there are negative financial effects such as the lost tax revenue resulting from intra-firm pricing policies minimizing taxable profits, the increased reliance over time upon Canadian financial sources for foreign investment, and impacts upon domestic savings. Product line and trade-pattern effects are encapsulated in the term "truncation." This suggests that foreign firms "copy" nearly the full product line of their parent on a much smaller scale, resulting in higher unit costs. Because the subsidiary produces such a similar line for the Canadian market, it 
is further suggested that the parent will inhibit export by the subsidiary which would compete with its own output. Also, the tie to the larger parent is likely to result in more purchases from integrated parent company establishments, instead of reliance on Canadian suppliers. Truncation incidentally also affects the technology issues in that the truncated subsidiary will not have a large $R$ \& $D$ effort duplicating the parent. Finally, foreign firms are said to reduce competition because they tend to be large in size and result in greater concentration in the given industry. Further, they are more likely to engage in activities where product differentiation prevails, which by itself means imperfect competition.

Safarian $^{12}$ gives one of the earliest critiques of the negative effects of foreign investment, in part pre-dating the government reports. He notes that while it is true that product lines of subsidiaries are "copies" in truncated scale, he argues this is attributable to the effect of tariffs on competition in Canada. As for exports and imports, he does not find any empirical evidence for differences in behavior between Canadian firms and foreign subsidiaries. On the view that competition is reduced because foreign firms are larger, the critics agree only that the firms are larger. Indeed they also agree that the foreign firms prevail in areas where product differentiation is important. However, they dispute the implication that such characteristics are inevitably bad,

${ }^{12}$ A.E. Safarian, Foreign Ownership of Canadian Industry, McGraw-Hill, 1966, and The Performance of Foreign Owned Firms in Canada, Canadian-American Committee, 1969. 
and emphasize that this may have nothing to do with the firms being foreign, but may be attributable to the lack of competition in Canada. In addition, Caves ${ }^{13}$ points out (though he does not find support for the thesis) that adding foreign firms can increase competition, encouraging greater efficiency. Globerman (1979 and 1979a) attempts to measure any such "spillover" effects foreign firms have upon the productivity of domestic firms, and concludes that they are small but positive. ${ }^{14}$ of course, his results incorporate not only the possible effects via increased competition, but any other spillover effects of a demonstration type: domestic firms observe and emulate new technologies, new managerial approaches, new product lines, etc. Indeed, the question of efficiency of production raised in the degree-of-competition discussion also has a technological dimension. The effects foreign firms may have upon technology and resultant productive efficiency, the last group of issues, is what we focus upon in this paper.

I.3. Review of Previous Analysis on Technology and Efficiency Technology and efficiency effects of multinational firms in Canada have three aspects in the existing literature: $R$ \& D activities by foreign firms in Canada; the assumption in global analyses of the net effect of foreign investment that the productivity of a

${ }^{13}$ R.E. Caves, "Multinational Firms, Competition, and Productivity in Host Country Markets," Economica, May 1974, pp. 176-191. Also suggested in Gorecki (1976).

${ }^{14} \mathrm{~S}$. Globerman, "Foreign Direct Investment and 'Spillover' Efficiency Benefits in Canadian Manufacturing Industry," Canadian Journal of Economics, February 1979, pp. 42-56. 
foreign dollar is exactly equal to that of a domestic one; and third, cost and productivity comparisons among domestic, foreign, and parent firms. The present study will not be able to contribute any new insights on the first of these, but it will permit a test of the assumption of equal productivity of investment, and will address directly the technology comparisons between foreign and domestic firms in a select group of industries.

There is a concern expressed by the Gray Report that indigenous development of an $R$ \& $D$ capacity is inhibited by the existence of foreign control of much manufacturing capital. Foreign subsidiaries, not wishing to duplicate "free" R \& D already done by parents will engage in less $R$ \& D than will comparable Canadian firms. Pollock ${ }^{15}$ refers to Canada's dependence on external technology, noting that 90 percent of patents issued in Canada are taken out by foreign applicants. But Safarian's study (1969) concludes that while foreign subsidiaries may do less $R$ \& $D$ than their parents, there is no evidence they do less than resident firms--indeed the opposite may be true. Although the question whether, on balance, one gains or loses from the existence of foreign firms is central to all the debate, few explicit attempts to quantify this exist. Two such studies have however been done in the past, by Penner in 1966 and by Powrie in 1977,16

\footnotetext{
${ }^{15}$ David Pollock, Canada and the Foreign Firm, Cuadermos de 1a Cepal, Santiago, Chile, 1976, Pp. 11-12.

${ }^{16}$ Rudolph Penner, "The Benefits of Foreign Investment in Canada, 1950 to 1956," Canadian Journal of Economics and Political Science, 32, No. 2, May 1966, pp. 172-183, and T.L. Powrie, "The Contribution of Foreign Capital to Canadian Economic Growth," mimeo, Department of Economics, University of Alberta, July 1977.
} 
both of which conclude that the effect is positive but very sma11. In both cases, it is assumed that technology differences between foreign and domestic capital are non-existent, that is the productivity of a dollar of investment is the same whether it be in a domestic firm or a foreign one. Inasmuch as other evidence on foreign firms' productivity--described below--suggests they are more efficient, these assumptions may cause an underestimate in the net gains. The proposed empirical analysis of this study will permit a direct test of the hypothesis that marginal product of capital is the same in both foreign and domestic firms.

Explicit cost and productivity comparisons of foreign and domestic firms have been undertaken in a number of studies. Safarian (1966 and 1969) looked expressly at unit costs, but compared only foreign subsidiaries in Canada with their parents, finding the former were usually much higher-cost producers. Labor productivity measures have been done by Raynauld (1972) ${ }^{17}$ and Globerman (1979a), in both cases using value-added per worker as the productivity measure. Raynauld found for 2,000 establishments in Quebec in 1961, the labor productivity in foreign firms was considerably higher than in domestic ones. The use of value-added per worker is of course subject to various criticisms to the effect that differences in this among firms may be due to industry characteristics, capital use, labor quantity, etc. Globerman, notes that without a fuller understanding of the sources of labor productivity one cannot

${ }^{17}$ Andre Raynauld, "The Ownership and Performance of Firms," in Gilles Paquet (ed.), The Multinational Firm and the Nation State, Toronto: The Ryerson Press, 1972. 
conclude that overall factor productivity is higher in foreign-owned firms. He attempts to explain labor productivity in different industries for Canadian firms in a regression analysis using a number of independent variables including proxies for labor quality, and capital labor-ratios, scale effects, hours worked, and the degree of foreign investment as a measure of the "spillover" benefits we noted earlier.

As Globerman's principal objective was to measure this "spillover" effect, he unfortunately did not analyze labor productivity of foreign firms, precluding any direct comparisons of the relative productivity of Canadian and foreign-owned firms. it is the purpose of our analysis to make such a comparison explicitly using establishment level production data to estimate translog production functions for Canadian and foreign-owned firms in the same industry.

II. THE PRODUCTION FUNCTION MODEL

In the estimation of production models the standard hypothesis is that the production function belongs to a restricted class which satisfies the a priori restrictions of positive monotonicity and quasiconcavity on factor inputs (see especially Nadiri ${ }^{18}$ ). The production functions most frequently used are the Cobb-Douglas, the $\mathrm{CES}$, and the translog, the last being a more recent development

18 M.I. Nadiri, 1978, "Producers Theory," in K.J. Arrow and M.D. Intriligator (eds.), Handbook of Mathematical Economics, Amsterdam: North Holland Publishing Company. 
(Christensen, Jorgensen, and Lau).$^{19}$ Each of these functions imply different restrictions in the properties of the technology. The Cobb-Douglas function restricts all Allen partial elasticities of substitution to be equal to one. The CES function restricts the above elasticities to be constant and equal for any pair of inputs and for all points in input space. In addition, both the CobbDouglas and the CES functions assume strong separability. The translog function, on the other hand, does not restrict the values of the elasticity of substitution at any point in input space; moreover, it does not assume strong separability. Therefore, the substitution possibilities depend on the level of all inputs.

The estimation of translog functions has become very popular lately for the flexibility that it provides (Berndt and Christensen; Berndt and Wood; Humphrey and Moroney). ${ }^{20}$ All these studies use a translog function with three inputs having nine regressors besides the constant, 21 (or ten including Hicks neutral technological change). To avoid multicollinearity problems and to increase the

${ }^{19}$ L.D. Christensen, D.W. Jorgenson, and L.J. Lau, 1971, "Conjugate Duality and the Transcendental Logarithmic Production Function," (abstract), Econometrica, 39.4, 255-256.

${ }^{20}$ E.R. Berndt and L.R. Christensen, 1973, "The Translog Function and the Substitution of Equipment Structures, and Labor in U.S. Manufacturing 1929-1968," Journal of Econometrics, 1, 1, 81-113. E.R. Berndt and L.R. Christensen, 1974, "Testing for the Existence of a Consistent Aggregate Index of Labor Inputs," American Economic Review, 64, 3, 391-404. E.R. Berndt and D. Wood, 1975, "Technology, Prices and the Derived Demand for Energy," Review of Economics and Statistics, 62,3, 259-268.

D.B. Humphrey and J.R. Moroney, 1975, "Substitution Among Capital, Labor and Natural Resource Products in American Manufacturing," Journal of Political Economy, 83, 1, 57-82. parameters.

${ }^{21}$ In general an $n$ input translog function has $2 n+\frac{1+n(n-1)}{2}$ 
size of the sample, the usual estimation procedure has been to work with side conditions for profit maximization in competitive product and factor markets. Under this assumption, side conditions for profit maximization imply a system of semi-logarithmic equations with one equation for each input. Each of these equations gives the cost share of an input as a linear function of the logs of each of the inputs. Problems of estimating a translog production function come from a decision as to how much information should be utilized. Three choices are available:

(1) Estimating the production function by itself.

(2) Estimating the parameters of the production function using only the side order conditions.

(3) Estimating the parameters of the production function using both the production function and the side order conditions simu1taneous 1 .

Methods (1) and (3) both require data on output. Consequently, studies using macro data will typically run into aggregation problems in constructing a measure of output. ${ }^{22}$ similarly, for time series analysis, methods (1) and (3) require an explicit structure for technological change, even in the Hicks-neutral case.

It can be argued that more efficient estimates may be obtained by using the full information system (3) compared to the limited

22 R.E. Ha11, 1973, "The Specification of Technology with Several Kinds of Output," Journal of Political Economy, 81,4, 878-892.

W.E. Diewert, 1974, "Applications of Duality Theory," in M. Intriligator and D. Kendrick (eds.), Frontiers of Quantitative Economics, Vol. II, Amsterdam: North Holland Publishing Company. 
information alternatives (1) and (2). Of course, as with any full information method, we can be confident of obtaining more efficient estimates only as long as the assumptions used to derive the system of equations are true. If they are not, a specification error is introduced which will have unknown consequences on the properties of our estimates. In particular, it is impossible to know if the parameters that one is estimating are those of a translog function, or a spurious set resulting from misspecification introduced by the use of untested and incorrect assumptions.

The advantages of method (2) vis-a-vis method (1) is that it reduces the problem of multicollinearity and increases the effective sample size. This, however, is done at the cost of making assumptions on firm behavior and market structure which are usually untested. Since method (3) incorporates the same assumptions (and "advantages") of method (2) as well as incorporating additional information on the structure of the production function which have been assumed but not used, method (3) is always more advantageous than method (2), if the specification of the production function is correct (especially the measure of output and the specification of the Hicks neutral technical change variable).

Corbo and Meller ${ }^{23}$ have used method (1) to estimate a translog function, for individual four-digit ISIC industries, in Chile using a cross-section of firms. Method (2) was initiated by Berndt and

${ }^{23}$ V. Corbo and P. Meller, "The Translog Production Function: Some Evidence from Establishment Data," Journal of Econometrics, $10,2,193-199,1979$, and V.Corbo, and P. Meller, "The Substitution of Labor, "Skill" and Capital in Chilean Manufacturing," Estudios de Economia, 1979 . 
Christensen (op. cit.) and has been used extensively since (see for example: Berndt and Wood (op. cit.), Humphrey and Moroney (op. cit.), Fuss, Moroney and Toevs, Pindyck. ${ }^{24}$ Surprisingly enough, the postulated hypothesis that the production function is of the translog variety, which was used in the derivation of the equations (side order conditions), was not included in the system of equations estimated.

Method (3)--the inclusion of the production function with the share equations--was suggested by Diewert (op. cit.) as a method for obtaining efficient estimates. it has been applied by Burgess and Appelbaum using the aggregate U.S. data of Berndt and Christensen; Brown, Caves and Christensen have used it in the context of a multiple output cost function on a cross-section of U.S. railroad data; and Breslaw, Corbo and Smith in the context of a firm.

In this study, we use Method (3) given its various advantages over the other two methods. We assume that within each four-digit SIC manufacturing industry and for a given ownership status al1

${ }^{24}$ M.A. Fuss, 1977, "The Demand for Energy in Canadian Manufacturing: An Example of the Estimation of Production Structures with Many Inputs," Journal of Econometrics, 5,1, 89-116. J.R. Moroney, and A.L. Toevs, 1977, "Factor Costs and Factor Use: An Analysis of Labor, Capital and Natural Resource Inputs," Southern Economic Journal, 44,2, 222-239. R.S. Pindyck, 1977, "Interfuel Substitution and the Industrial Demand for Energy: An International Comparison," MIT, Working Paper EL 77-026 WP.

$25_{E}$. Appelbaum, 1978, "Testing Neoclassical Production Theory," Journal of Econometrics, 7,1, 87-102. J. Breslaw, V. Corbo and J.B. Smith, 1979, "A Micro Test of the Neoclassical Production Theory," Manuscript only. R.S. Brown, D.W. Caves, and L.R. Christensen, 1976, "Modelling the Structure of Production with a Joint Cost Function." Manuscript only. D.F. Burgess, 1975, "Duality Theory and Pitfalls in the Specification of Technologies," Journal of Econometrics, 3,2, 105-121. 
establishments use the same technology. We assume further that firms are cost minimizers subject to a translog technology. Thus, we assume that the observations on putput and inputs are generated from the following model:

$$
\text { Minimize } \quad \mathrm{C}=\mathrm{wL}+\mathrm{m} \mathrm{M}+\mathrm{v} \mathrm{K}
$$

subject to:

$$
\begin{aligned}
& \text { (1) } \\
& \ln \mathrm{Y}_{i j}={ }_{0}^{i}+\alpha{ }_{0}^{i} \ln \mathrm{L}_{i j}+\alpha{ }_{2}^{i} \ln \mathrm{M}_{i j}+\alpha{ }_{3}^{i} \ln \mathrm{K}_{i j} \\
& +\frac{1}{2} \gamma_{11}^{i}\left(\ln L_{i j}\right)^{2}+\gamma_{12}^{i}\left(\ln L_{i j}\right)\left(\ln M_{i j}\right) \\
& +\gamma_{13}^{i}\left(\ln L_{i j}\right)\left(\ln K_{i j}\right)+\frac{1}{2} \gamma_{22}^{i}\left(\ln M_{i j}\right)^{2} \\
& +r_{23}^{i}\left(\ln \mathrm{M}_{i j}\right)\left(\ln \mathrm{K}_{i j}\right)+\frac{1}{2} \gamma_{33}^{i}\left(\ln \mathrm{K}_{i j}\right)^{2}
\end{aligned}
$$

where $\mathrm{Y}$ is value of production, $\mathrm{L}$ is labor, $\mathrm{M}$ is materials, $\mathrm{K}$ is capital, $i$ is an index of a four-digit SIC industry, and $j$ is an index of a firm within the ith industry.

In equation (1) we are assuming that every establishment within a four-digit SIC industry, independent of size and other characteristics, has the same production function. However, recalling that in a translog function the elasticity of substitution is different at every data point, the size of the establishment will affect the substitution properties of the technology.

The hypothesis of constant returns to scale can be tested directly from (1). Constant returns to scale imply the following restrictions on the parameters of this function for sector $i$ (E. Berndt and L. Christensen, 1973, p. 84). 

(i) $\sum_{\mathrm{k}=1}^{3} \alpha_{k}^{\mathbf{i}}=1$
(iii) $\sum_{s=1}^{3} \alpha_{s k}^{i}=0$
$k=1,2,3$
(ii) $\begin{aligned} & \sum_{k=1}^{3} \alpha_{s k}^{i}=0 \\ & s=1,2,3\end{aligned}$
(iv) $\sum_{s=1}^{3} \underset{\substack{\sum \gamma \\ k=1}}{3 i}=0$

With symmetry imposed a priori, restrictions (iii) and (iv) are not independent of (i) and (ii). Therefore, we test for constant returns to scale in model (1) by imposing constraints (i) and (ii) on the parameters.

A production function is considered to be well-behaved if it has positive marginal products for each input (monotonicity) and if it is quasi concave. The translog function does not satisfy these restrictions globally. Still, if we can find wide enough regions in input space (including the observed input combination) where these restrictions are satisfied, we can consider the translog function as well-behaved for relevant input combinations. To do this, monotonicity and quasi-concavity of the estimated translog function must be checked at every data point in the sample.

Monotonicity requires $\partial \mathrm{Y} / \partial \mathrm{L}>0, \partial \mathrm{Y} / \partial \mathrm{M}>0$ and $\partial \mathrm{Y} / \partial \mathrm{K}>0$; differentiating the translog function we find:

$$
\begin{aligned}
& F 1_{i j}=\frac{\partial Y_{i j}}{\partial L_{i j}}=\frac{Y_{i j}}{L_{i j}}\left(\alpha_{1}^{i}+\gamma_{11}^{i} \ln L_{i j}+\gamma_{12}^{i} \ln M_{i j}+\gamma_{13}^{i} \ln K_{i j}\right) \\
& F 2_{i j}=\frac{\partial Y_{i j}}{\partial M_{i j}}=\frac{Y_{i j}}{M_{i j}}\left(\alpha_{2}^{i}+\gamma_{12}^{i} \ln L_{i j}+\gamma_{22}^{i} \ln M_{i j}+\gamma_{23}^{i} \ln K_{i j}\right) \\
& F 3_{i j}=\frac{\partial Y_{i j}}{\partial K_{i j}}=\frac{Y_{i j}}{K_{i j}}\left(\alpha_{3}^{i}+\gamma_{13} \ln L_{i j}+\gamma_{23}^{i} \ln M_{i j}+\gamma_{33} \ln K_{i j}\right)
\end{aligned}
$$


Using these expressions, we compute the relevant partial derivatives, given a set of parameter values, for each sample point of input and output values, in order to check for monotonicity. The translog function is strictly quasi-concave (strictly convex isoquants) if the bordered Hessian matrix is negative definite. In the case of three inputs this requires the bordered principal minors to be positive and negative respectively. 26

First order conditions for cost minimization subject to equation (1) yields the following equation:

$$
\begin{aligned}
& w_{i}=\lambda F_{i j}^{1} \\
& m_{i}=\lambda F_{i j}^{2} \\
& v_{i}=\lambda F_{i j}^{3}
\end{aligned}
$$

where $\lambda$ is the lagrangian multiplier of the cost minimization problem. Eliminating $\lambda$ from these first order conditions we obtain:

$$
\begin{aligned}
& {\frac{m_{i}}{w_{i}}}_{w_{i j}} \frac{F 2}{i j} \\
& \frac{v_{u}}{w_{i}}=\frac{F 3_{i j}}{F 1_{i j}}
\end{aligned}
$$

Substituting on the right hand side the expressions found above we obtain:

\footnotetext{
${ }^{26}$ Takayama, A., 1974, Mathematical Economics, Hinsdale, Illinois: The Dryden Press. See p. 123.
} 
(2) $\frac{m_{i} M_{i j}}{w_{i} L_{i j}}=\frac{\alpha_{2}^{i}+\gamma_{12}^{i} 1 \mathrm{~nL}_{i j}+\gamma_{22}^{i} 1 \mathrm{nM}_{i j}+\gamma_{23}^{i} \operatorname{lnk} \mathrm{K}_{i j}}{\alpha_{1}^{i}+\gamma_{11}^{i} \operatorname{lnL}_{i j}+\gamma_{12}^{i} \operatorname{lnM}_{i j}+\gamma_{13}^{i} 1 u K_{i j}}$

(3) $\frac{v_{i} \quad k_{i j}}{w_{i} \quad L_{i j}}=\frac{\alpha_{3}^{i}+\gamma_{13}^{i} 1 n L_{i j}+\gamma_{23}^{i} 1 n M_{i j}+\gamma_{33}^{i} \operatorname{lnk} K_{i j}}{\alpha_{1}^{i}+\gamma_{11}^{i} \operatorname{lnL} L_{i j}+\gamma_{12}^{i} 1 n M_{i j}+\gamma_{13}^{i} 1 n K_{i j}}$

The system formed by equations (1), (2) and (3) is estimated jointly as a system of seemingly unrelated equations.

The estimated coefficient values of equation (1) are then used to calculate the usual production parameters: marginal factor productivities; factor elasticities; substitution elasticities; factor ratios; and average and marginal costs. Furthermore, the coefficients are used to simulate optimal factor ratios for given different values of output scale and factor prices. This procedure permits one to do two things. First, we can separate the effects of technology differences, scale, and factor-prices upon the optimal ratios of capital to labor, as well as materials to labor. Figure 1 illustrates this procedure for a comparison between Canadian-owned and U.S.-owned firms, where it is supposed there is a difference in technology between the two, with U.S. firms (for convenience, we will use the terms "U.S. firms" and "Canadian firms" to denote the country of ownership) producing on average at higher levels of output (AQU) 
FIGURE 1

SIMULATING LEAST-COST FACTOR-INPUTS FOR U.S. FIRMS

USING CANADIAN SCALE AND FACTOR PRICES

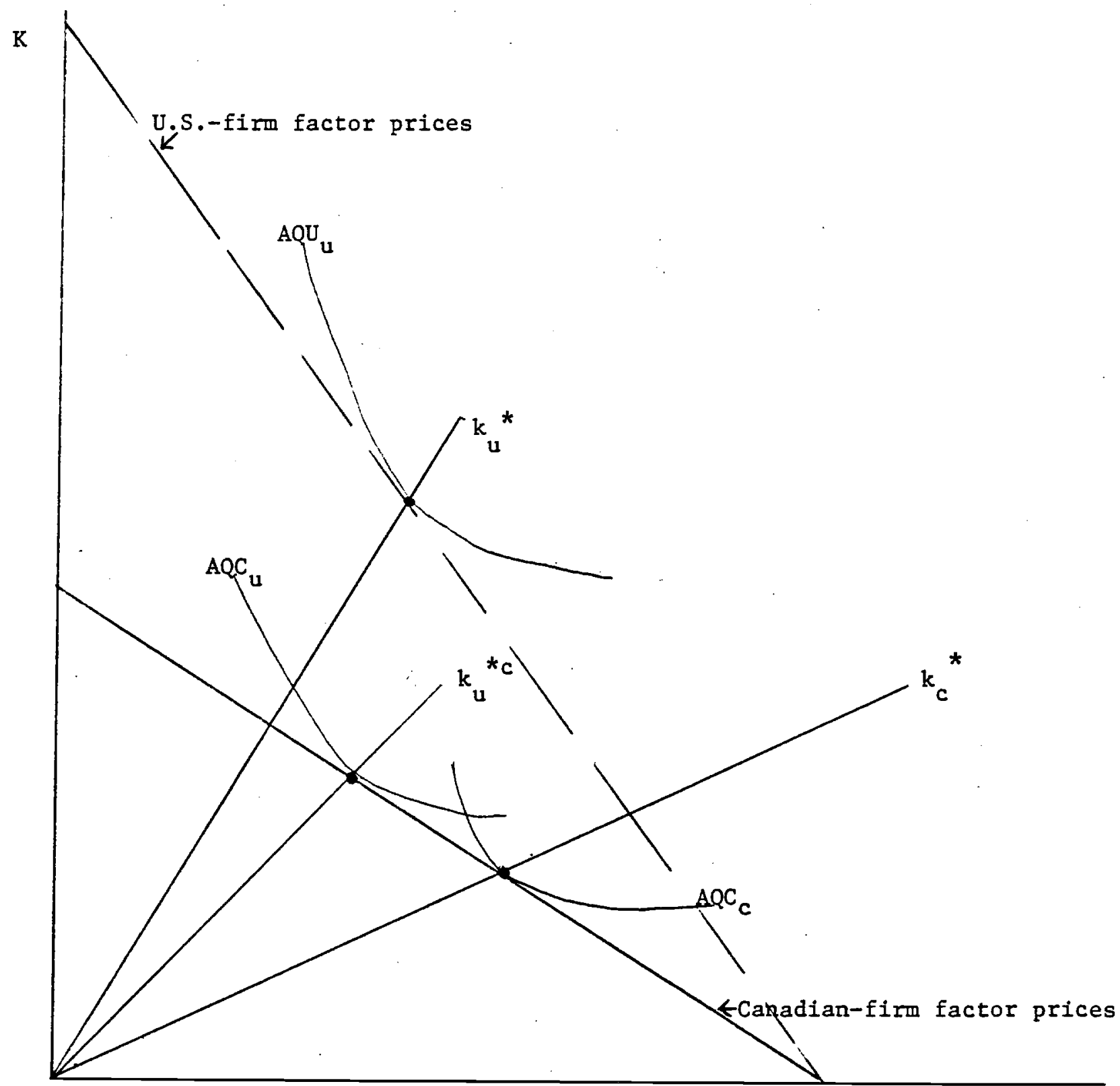


than Canadian ones ( $A Q C$ ), facing relatively higher wage-rental ratios, and using relatively higher capital-labor ratios ( $k *$ compared to $\left.k_{c}^{*}\right)$. If U.S. firms are then assumed to face Canadian-firm factor prices and produce at Canadian scales but using "U.S." technology, the result would be production on isoquant $\mathrm{AQC}_{\mathrm{u}}$ at a capital-labor ratio $k_{u}{ }^{*} c$, lower than $k_{u}{ }^{*}$ but still higher than $k_{c}{ }^{*}$. This reflects the fact that the technology used by U.S. firms is still more capital intensive than that used by Canadian firms, even at the same lower Canadian-firm scale and with similar factor prices. This is done for actual coefficient values by using U.S.-firm coefficients as in equation (1), Canadian output levels and factor-input prices, and solving the system of equations for the three inputs: capital, labor, raw materials, to arrive at a cost-minimizing combination. Secondly, the simulation of the optimal values $k^{*}$ for each ownership category also allows one to judge "efficiency." The closer actual $k$ values are to $k^{*}$ the more "efficient" the firms in the industry. One can therefore observe whether U.S.-owned firms and more "efficient" than Canadian-owned ones by comparing ( $k_{\text {actual }}-k^{*}$ ) for certain groups. 
III. DATA AND EMPIRICAL RESULTS

\section{1. Production Function Estimates}

The basic units of information are production data for an establishment as defined in the Canadian Manufacturing Census, in the years 1972 and 1975. The number of establishments varies by industry and by ownership. In table 1 we present for 1972 the number of establishments in the census in the different industries considered in this study. 27

The definitions of the input variables used in our estimations are as follows:

$0=$ Quantity index of production: measured as the current value of production divided by the industry selling price index.

$\mathrm{L}=$ Number of man hours of production workers equivalent: defined as the sum of wages and salaries divided by the wage rate of production workers.

$M=$ Quantity index of raw materials: Current dollar values divided by a sector specific price index of raw materials.

$\mathrm{K}$ = Capital Services: measured as proportional to the constant dollar consumption of fuel and electricity. The factor of proportionally $(\theta)$ is estimated jointly ith he other parameters in the systems of equation (1) to (3).

27 The data used is from a special subset of the Census in which ownership of an establishment is flagged. We are grateful to Statistics Canada for their permission to use results of regressions run on this data set, and especially to John McVey for his cooperation and assistance in the analysis. 


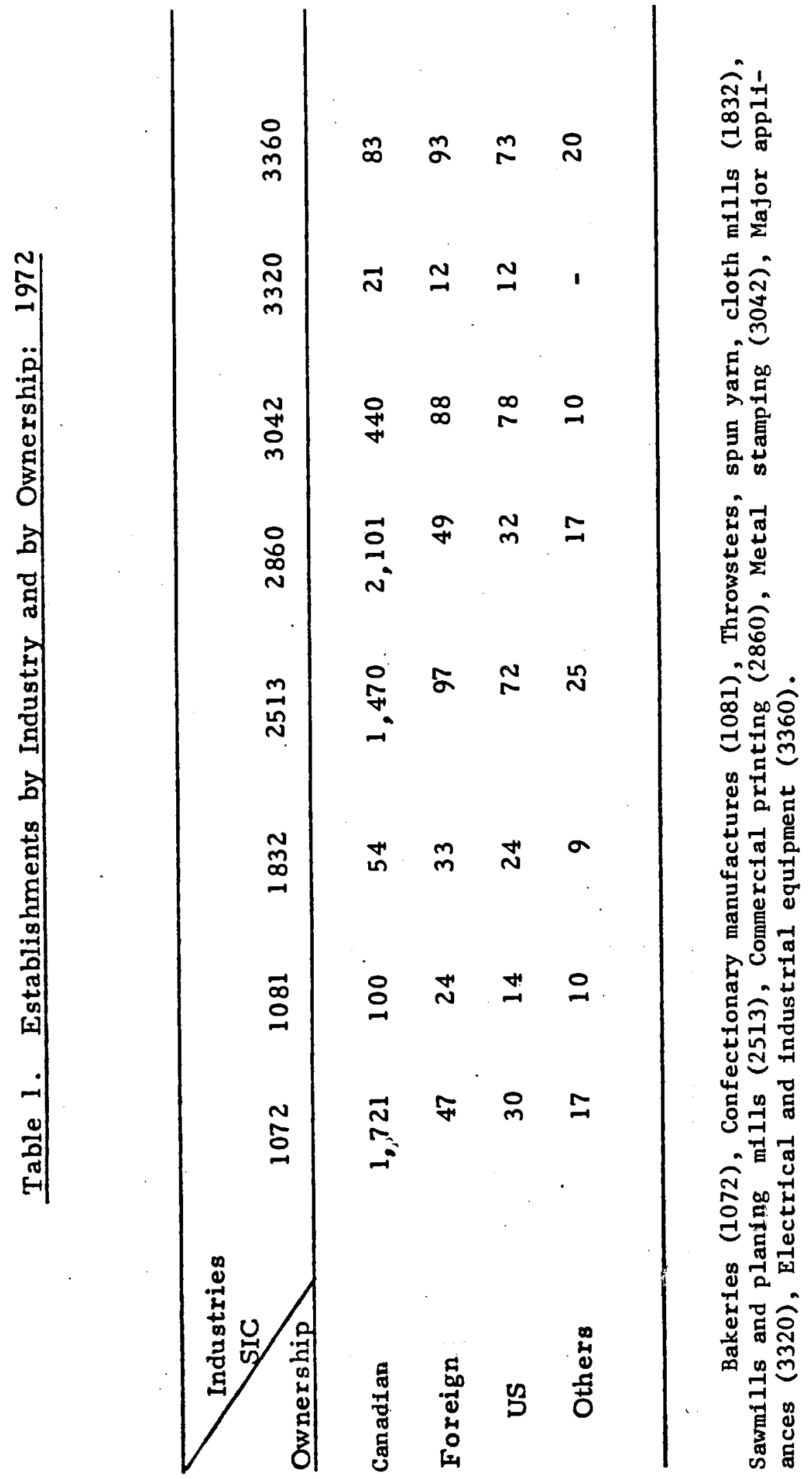




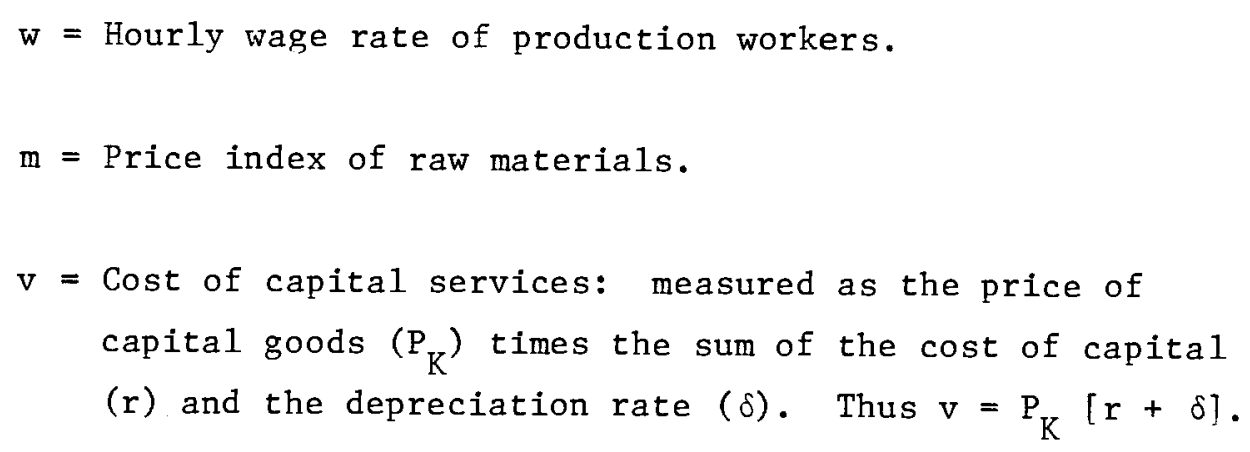

The whole system was estimated using the non-linear least squares (NLLSO) estimating procedure. A difficulty with the use of NLLSQ is that the regressors (the factor quantities) are endogenous variables for an establishment within an industry. Failure to take account of this will introduce contemporaneous correlation between the regressors and the random error of the individual equations (the simultaneity problem). In such a case the NLLSQ estimates of equations (1) to (3) are biased and inconsistent. Consistent estimates could be obtained by using a nonlinear instrumental variable (NLIV) estimator; however, in cross section analysis the usual instruments--lagged values of the explanatory variables--are usually so correlated with the variables for which they are serving as instruments that the NLLSQ and NLIV results are not very different. $^{28}$ Therefore, we have estimated our model using NLLSQ. Due to differences in the size of individual establishments within an industry the problem of heteroscedasticity could arise.

${ }^{28}$ In the context of time series estimates of an aggregate production function for the manufacturing sector the same result was found by E. Berndt and L. Christensen (1973, Tables 4,6,7). 
This is minimized in our estimation procedure because we work with all the variables scaled in such a way that their means are equal to one.

In table 2 we present the results obtained for the point estimation of equations (1), (2) and (3). The results overall are very good, most of the cross terms are highly significant and thus we encounter no problem in the estimation of elasticities of substitution and other parameters of the technology. One exception occurs: the inability to estimate coefficients for U.S.-owned bakeries.

III.2 Comparison of Technology Parameters: U.S. and Canadian Firms

Table 3 presents the calculated values of seven productionrelated parameters for the seven industries other than 1072--Bakeries, for Canadian- and U.S.-owned firms. ${ }^{29}$ These enable one to "test" some of the hypotheses from the literature reviewed in Section II. 3 above, at least in an indicative way based on this limited sample.

In general, it is thought unit costs are lower in U.S. firms (Safarian, 1966 and 1969). If one considers marginal costs, this is true only in three cases $(1081,2860$, and 3320), in two others costs being the same (3042 and 3360), while in the three others, Canadian-owned firms have lower costs. Note also that for two of the industries where U.S. firms have lower marginal costs--1081 and $3320--$ the sample size for U.S. firms is very small. Much the same conclusion emerges looking at average costs, for which we find U.S.

\footnotetext{
${ }^{29}$ other foreign-owned firms are excluded since in most cases the sample size is quite small.
} 


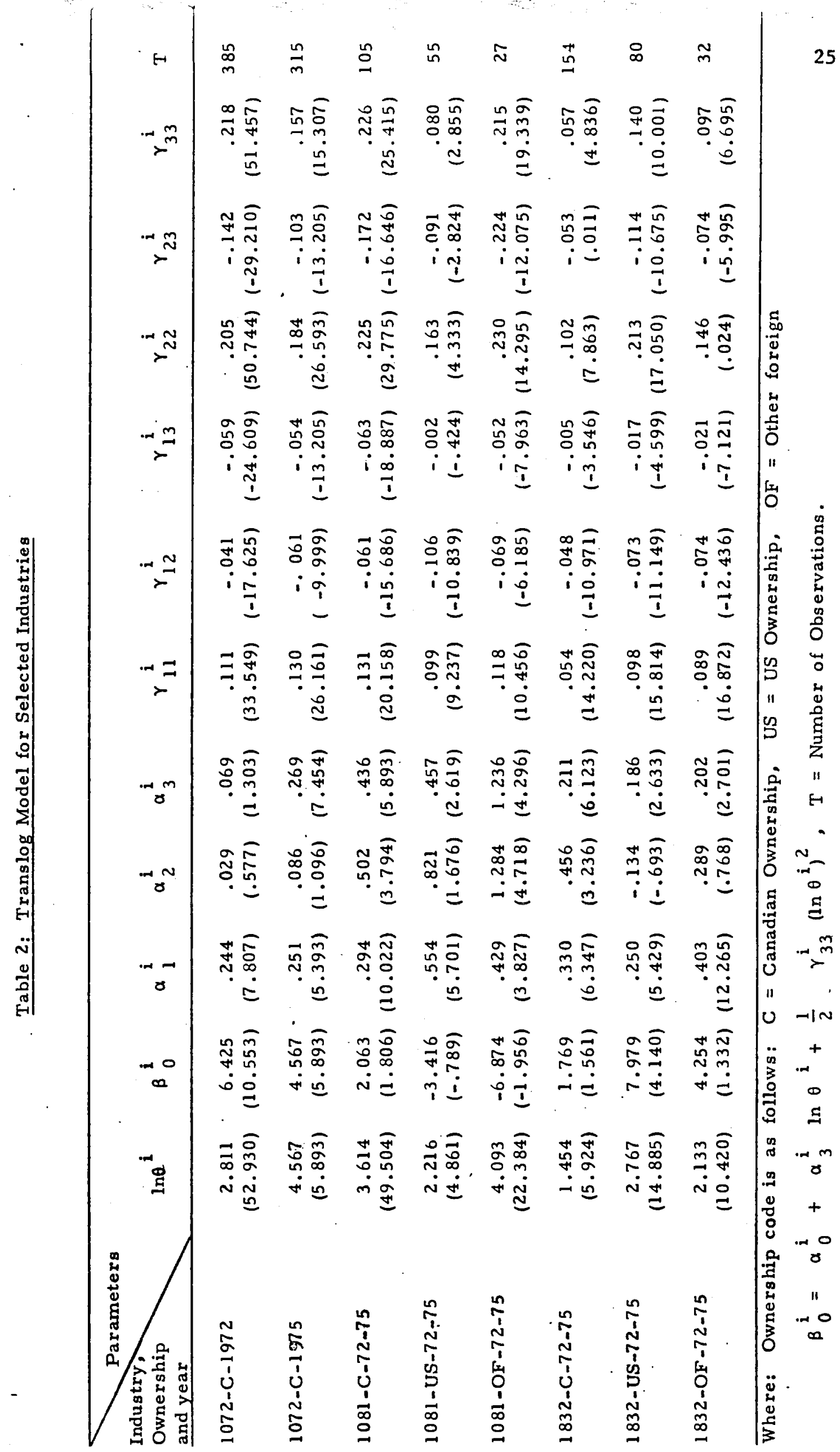




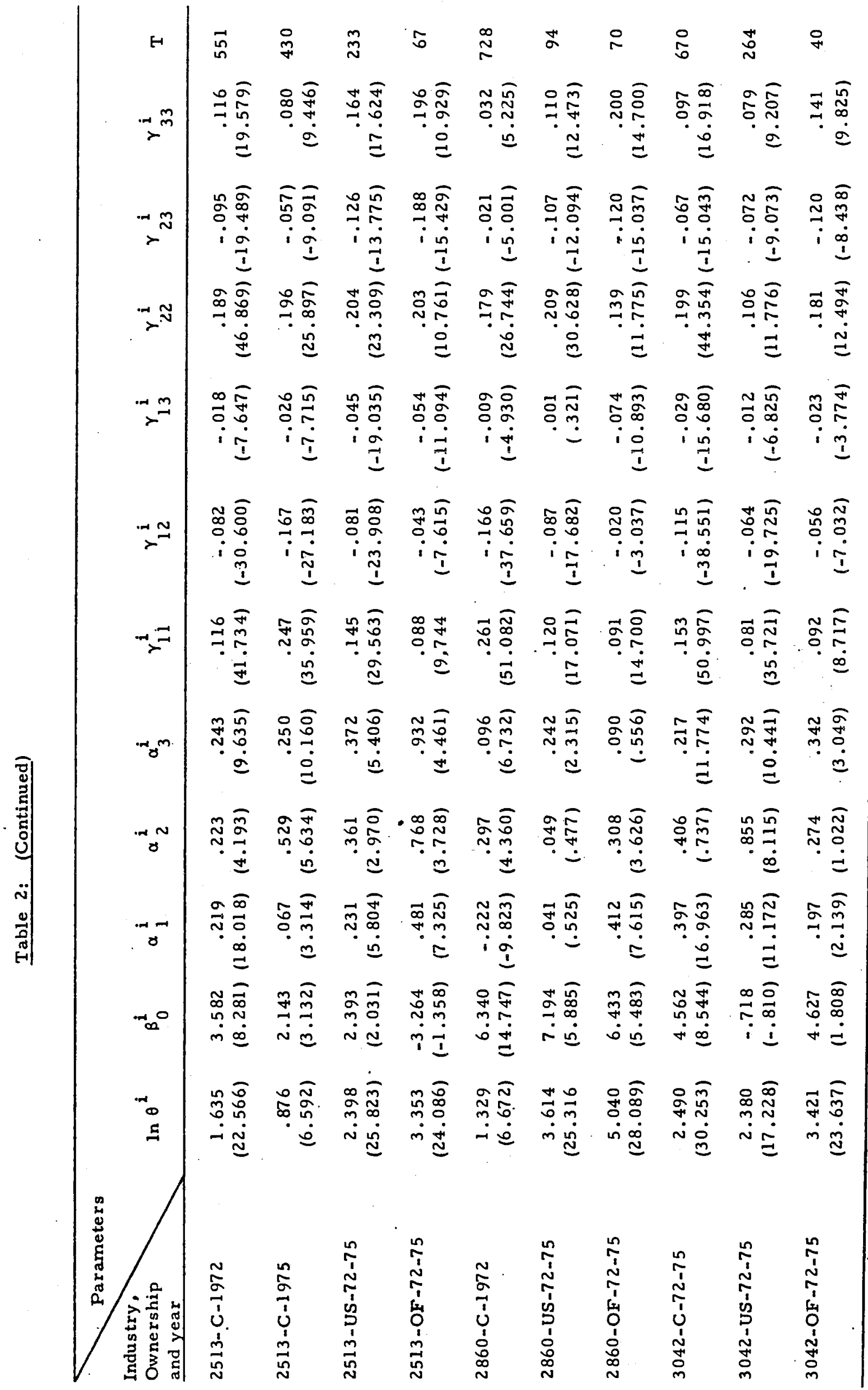




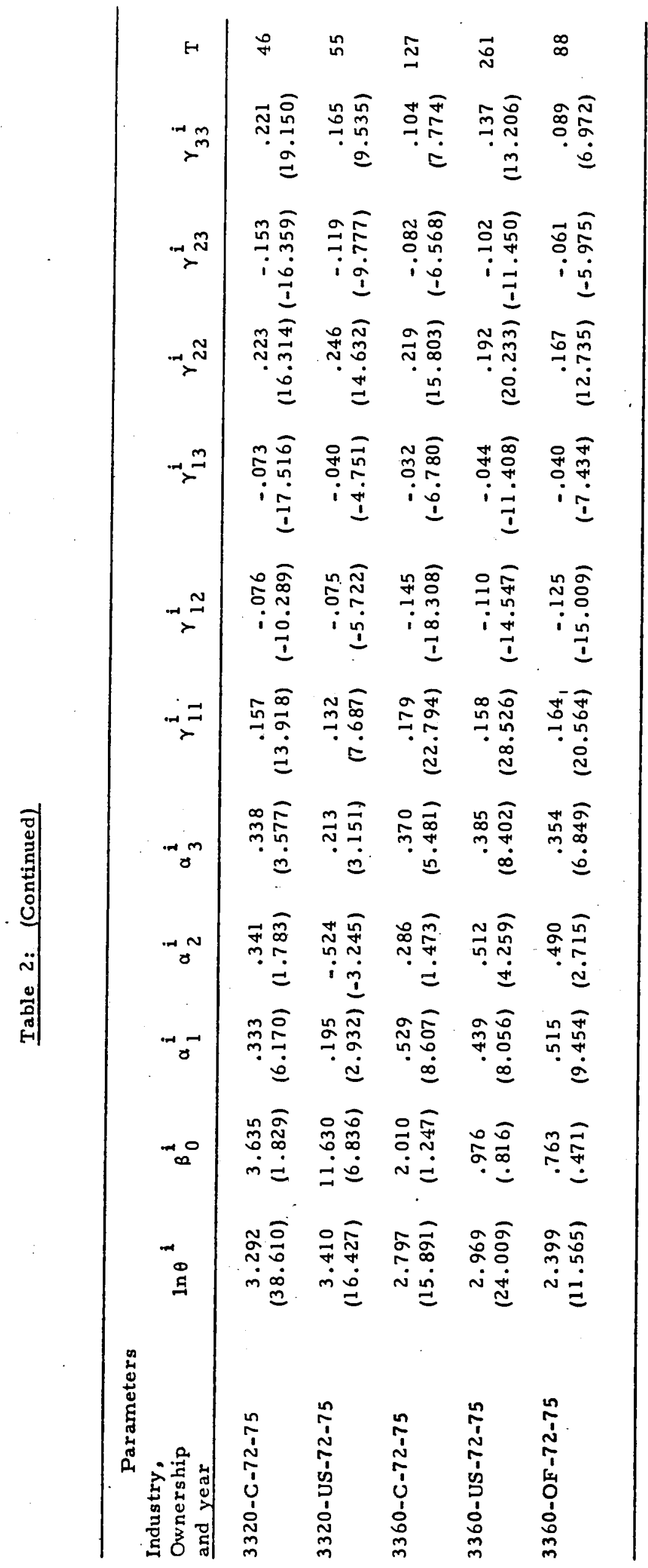




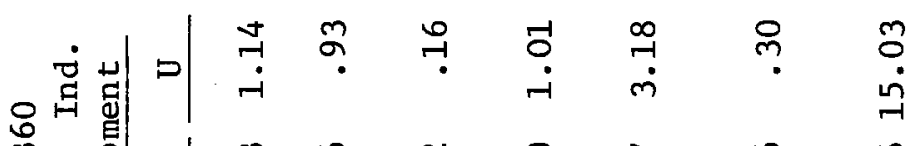

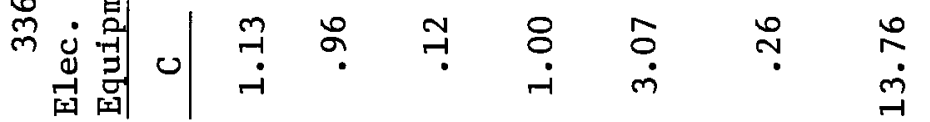

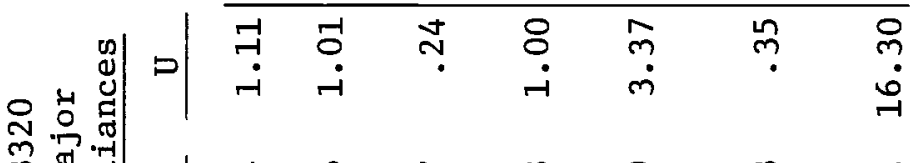

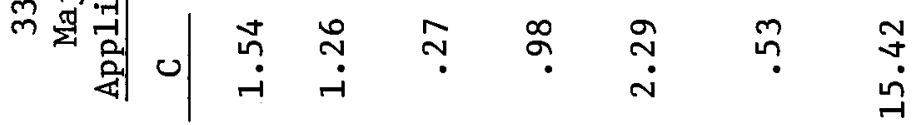

哇

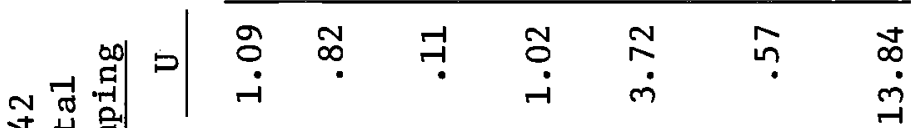

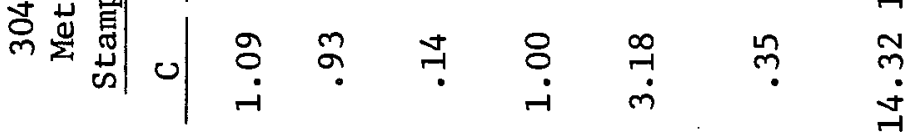

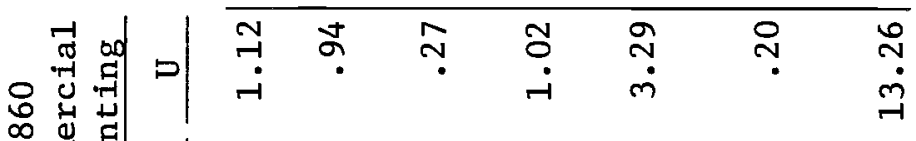

狊喿|

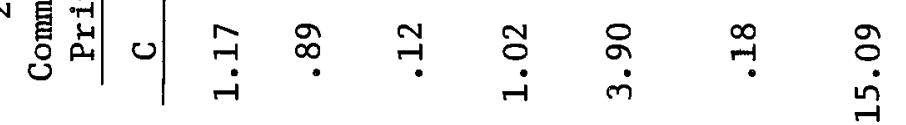

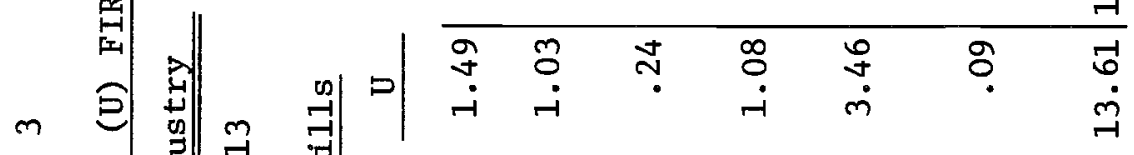

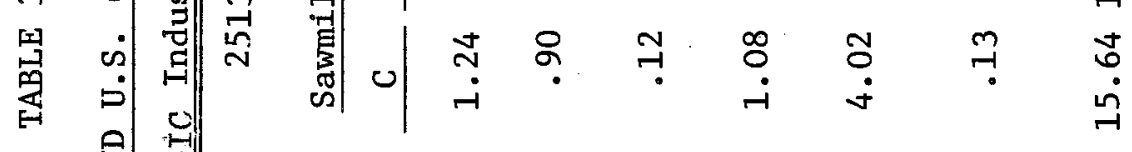

会 别

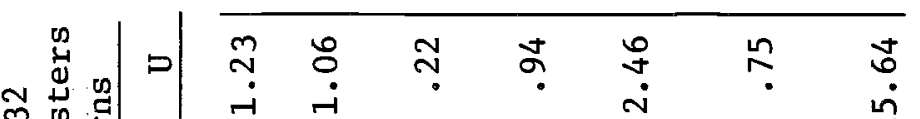

की

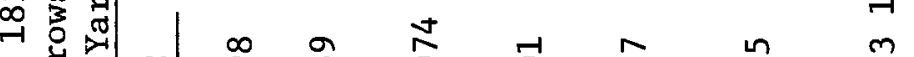

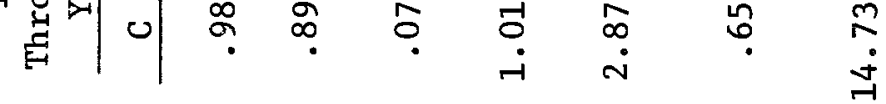

忽

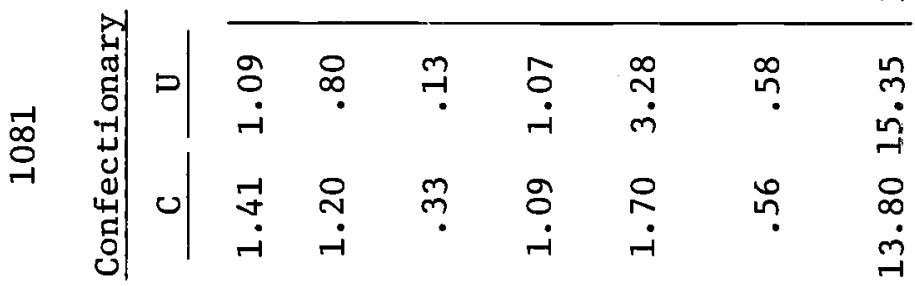

â

$\stackrel{\infty}{0} \stackrel{n}{0}$

$\stackrel{\ln }{\infty} \quad$ in

$\stackrel{9}{i} \quad \stackrel{0}{+1}$

$\stackrel{0}{\sim} \quad \stackrel{0}{\sim}$

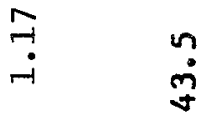
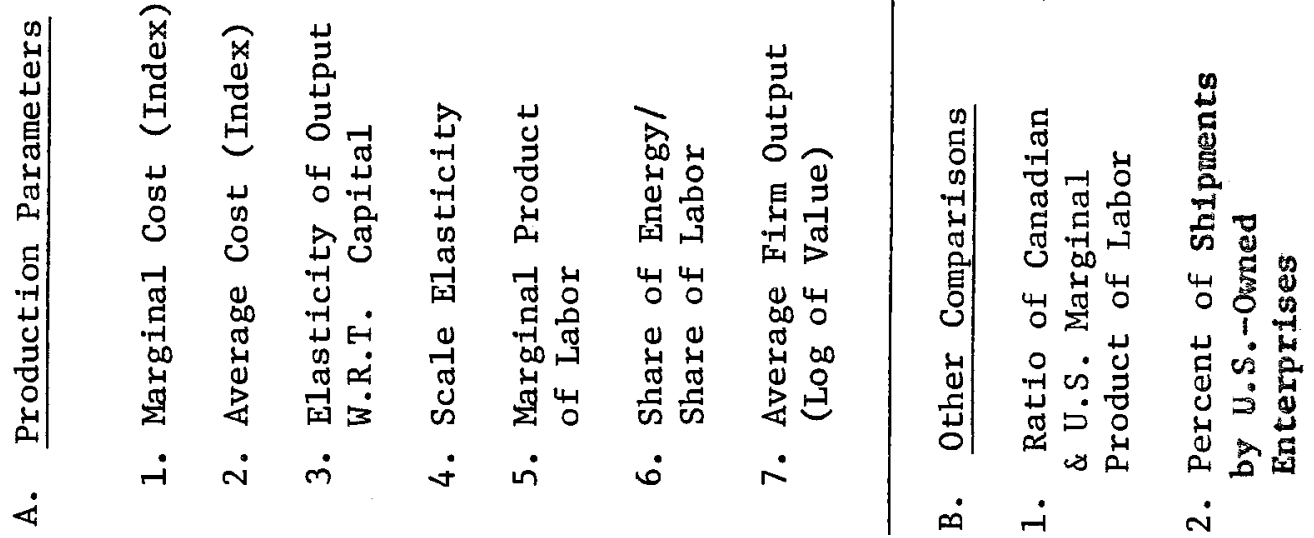
firms are lower cost in four of seven industries. Thus, it would appear from our estimates that U.S.-owned firms are by no means consistently lower-cost producers.

Analyses of overall benefit-cost effects of foreign ownership as done by Penner, and later Powrie, assumes a dollar of investment by U.S. or Canadian firms results in equal output. Again, our parameter values cast doubt on the generality of this assumption, as we observe that the elasticity of output with respect to capital is greater in U.S.-owned firms in four of seven cases. That this is not affected very much by scale effects is clear from a comparison of the scale elasticity values. In all cases but one, the scale effect is almost exactly the same in Canadian and U.S.-owned firms. We emphasize again the limited size of this sample, as a consequence of which our conclusions cannot readily be generalized. However, from this sample it would appear that the effect of a dollar investment is in some industries higher for U.S.-owned firms, and in other industries it is higher in Canadian-owned ones, and that therefore in aggregate. assuming overall equal effects may not be unreasonable, but it is more correct to look at specific industries. Another hypothesis reviewed earlier stated that in general labor productivity is higher in U.S.-owned firms. Production function coefficients permit one to measure labor productivity not simply as a value-added labor input ratio, but as the basic theoretical concept of marginal product of labor, ceteris paribus. 
Again, our (admittedly limited) test casts some doubt on the conventional hypothesis. We find the marginal product of labor is higher in only four of seven cases, a "majority" but by no means a clear reflection of the conventional view. Our test of the hypothesis is of course as much a statement about the inappropriateness of using simple output:labor ratios to measure labor productivity as it is a rejection of the view that labor productivity is higher in U.S.-owned firms.

Related to this issue is the hypothesis of Globerman that there may be spillover effects on the productivity of Canadian-owned firms, which are greater the higher the degree of ownership in an industry. Globerman's empirical test of this had two shortcomings: first, he did not actually measure labor productivity in U.S. vs Canadian firms; and secondly, he used the simpler partial productivity measure, output:labor ratio. For the seven industries studied here, no confirmation of this hypothesis is found. If such spillovers existed, we should expect some positive correlation between the ratio of Canadian marginal product of labor to U.S. marginal product of labor, and the degree of U.S. ownership. That is, we might expect Canadian productivity to be closer to U.S. productivity where foreign ownership was greatest. In fact, if anything, the correlation is slightly negative, as can be easily observed in Panel $\mathrm{B}$ of Table 3 . Though by no means a refutation of Globerman's spillover hypothesis, this certainly does not give it strong support.

The last two parameters in Panel A of Table 3 are "Share of Energy/Share of Labor," a proxy for capital-labor ratios, and "Average Output" shown as $\log$ of value. As is well documented 
elsewhere, U.S.-owned firms are generally larger, and are usually thought to be more capital intensive. In all seven industries, U.S.-owned firms are indeed larger, and the proxy for capital-labor is greater in all but one instance, and this last case the estimates shown had standard deviations equal to about half of the mean. But it is by no means clear that this is universally associated with lower marginal or average costs, or with greater capital productivity, or greater scale economy effects, or greater labor productivity. Our results only confirm that U.S. firms more often than not have higher "productivity" or lower "costs," but there are many instances of the reverse situations, suggesting at the very least that the supposed superiority of U.S. firms is far from universal.

III.3 Simulation Analysis of Technology Differences: Canadian and

\section{U.S.-Owned Firms}

Following the procedure described earlier for simulating optimal (i.e. least-cost) factor-input levels in each industry, given outputs and technological coefficients of the system of equations (1), (2), (3), we present here a comparison of Canadian-owned and U.S.-owned firms. First, optimal inputs are simulated for Canadian-owned and U.S.-owned firms separately using own scale and factor-price levels. The resulting capital-labor ratio values are shown as $k_{c}^{*}$ and $k_{u}{ }^{*}$ in Table 4 . Then we simulate the optimal factor ratio U.S. firms would use if they were to produce at the Canadian-firm scale and face the factor prices of Canadian firms but used their own technology as reflected in the parameters of Table 2. 
TABLE 4

SIMULATED OPTIMAL CAPITAL-LABOR RATIOS

(\$/Man Hour)

\begin{tabular}{|c|c|c|c|c|}
\hline 非 & Name & $\begin{array}{c}\text { anadian Firms } \\
{ }^{* *}{ }_{\mathrm{C}}\end{array}$ & $\begin{array}{c}\text { U.S. Firms } \\
{ }_{\mathrm{k} *}{ }_{\mathrm{U}}\end{array}$ & $\begin{array}{c}\text { U.S. Firms } \\
\text { Canadian Scale } \\
\text { and Prices } \mathrm{k} * \mathrm{U}\end{array}$ \\
\hline 1081 & Confectionery & 4.55 & 2.09 & 1.47 \\
\hline 1832 & Throwsters, yarns & 0.71 & 2.99 & 3.04 \\
\hline 2513 & Sawmills & 2.45 & 2.36 & 2.47 \\
\hline 2860 & Commercial Printing & 0.70 & 2.92 & 4.36 \\
\hline 3042 & Metal Stamping & 0.72 & 2.48 & 2.29 \\
\hline 3320 & Major Appliances & 3.37 & 2.21 & 1.56 \\
\hline 3360 & $\begin{array}{l}\text { Electrical Industrial } \\
\text { Equipment }\end{array}$ & 0.69 & 1.29 & 1.26 \\
\hline
\end{tabular}


The resulting capital-1abor ratio is shown as $k_{u}{ }^{*} c$. The difference between $k_{c} *$ and $k_{u}{ }^{*}$ is assumed to be attributable to three factors: scale effects upon technology, different factor prices, and technology differences. The simulated ratio $\mathrm{k}_{\mathrm{u}}{ }^{* \mathrm{C}}$ incorporates the scale and factor-price effects, hence the difference between this value and the value $k_{c} *$ is due only to technology differences. With this, we can test directly the hypothesis that U.S.-owned firms use different technologies from Canadian-owned firms.

Before we discuss these results, a very brief digression on different factor prices is appropriate. Although this possibility contradicts the fundamental assumption of a homogeneous factor market, it is by no means an uncommonly observed phenomenon with regard to multi-national subsidiaries, especially in small economies. Lower capital costs are often alleged to prevail in foreign-owned firms because they are thought to have access to larger pools of parent-company capital and/or credit-worthiness. This can of course sometimes go in the opposite direction, namely that the larger parent firm may, elsewhere in the world, have better profit-making opportunities than the subsidiary in question, in effect making the global internal opportunity cost of capital higher, despite the lower supply-price resulting from larger capital pools. Although this alone justifies assuming different wage-rental ratios, there is also sometimes an argument that multinationals willingly pay higher wages than the going market rate, in order to try to attract the best labor 
and to act in a way favorable to thelr inage as good corporate citizens of the host country. 30

Simulated capital-labor ratios using own factor prices and scale levels show much the same picture as the proxy parameter "Share of Energy/Share of Labor" in Table 3. In the majority of industries four Canadian-owned firms have lower capital-labor ratio values, in one industry it is about the same, and in two cases Canadian ratios are higher. The simulated optimal values correspond closely with the actual measured ratios, indicating both the reasonableness of the methodology of estimation and the fact that firms are, on average, efficient in the sense of being on the isoquant optimality point. ${ }^{31}$ The one exception to this is industry 2513 (Sawmills), where the proxy measure of actual capital-1abor ratio used (Share of energy/Share of labor) shows U.S.-owned firms have higher capital-intensity, whereas the optimal ratio simulated shows they are very slightly lower. 32

If we consider next what happens to the capital-labor ratio of U.S. firms when Canadian-firm scale and factor prices apply, we observe what appear at first to be anomalies, but in fact reflect a

30 These arguments are discussed for developing countries in Lall and Streeten, op. cit., as well as for Canada in S. Kardacz, "Foreign Control and Investment Behavior: A Case Study of Two Firms in the Canadian Electrical Products Industries," Ph.D. Dissertation, 1976, Queen's University: Kingston, Canada.

${ }^{31}$ D. Aigner, C.A. Knox Lovell, and Peter Schmidt, "Formulation and Estimation of Stochastic Frontier Production Functions," Journal. of Econometrics, 6, 1977, pp. 21-37.

32

of the twenty-one simulations done, this was the only one that gave a local solution only, rather than a global one. Thus, the values shown in Table 4 may not be a correct representation, due to an econometric convergence problem. 
point made earlier: that wage-rental ratios are not always higher for U.S.-owned firms. In only two cases do we find the results that conventional wisdom on U.S. firms in Canada leads one to expect: a higher capital intensity in U.S. firms, and a higher wage-rental ratio, resulting in a lowering of $k_{u}$ values, part of the way, when Canadian scale and factor prices are applied. These are industries, 3042 (Metal Stamping) and 3360 (Electrical Industrial Equipment). In two other instances, 1832 (Throwsters and Yarns), and 2860 (Commercial Printing), while U.S. firms have higher $k$ ratios, these Iise when Canadian scale and factor prices are applied. For 2860, this results because the wage-rental ratio is found to be lower for U.S.owned firms (3.45 compared to 4.03). This fact is somewhat unexpected and differs from the situation of most other industries where U.S. firms have higher wage-rental ratios. In the other industry, the higher U.S. capital-labor ratio rises imperceptibly from 2.99 to 3.04 . This may not signify a true difference, but taking this at face value, we observe that this happens despite a marginally higher wage-rental ratio. Such a relationship implies the existence of a non-homothetic production function for U.S.-owned firms, with the expansion path concave to the L-axis. If such is the case, it clearly suggests a distinctly different technology, although as noted the movement may not be statistically significant.

Finally, in three other instances, Canadian-owned firms have higher capital-labor ratios, and simulated U.S. ratios fall in two cases (1081 Confectionary, and 3320 Major Appliances), while rising 
slightly in the third (2513 Sawmills). For the first two, Canadian wage-rental ratios are distinctly lower, explaining the fall in U.S. ratios. For the third case, wage-rental ratios are also lower for Canadian-owned firms; however, the simulations for this industry were troublesome, as noted, giving only a local solution to the system of equations, and, in any event, the differences in $k$ values are quite small.

Last, we turn to analyze Table 4 values as to what they imply about the existence of technology differences. In general, we find only one industry where the simulated $\mathrm{k}$ value, incorporating scale and technology effects, eliminates the difference between initial $\mathrm{k}$ values; with the conclusion that no technology differences exist. This industry is 1832 , for which the simulated results are first statistically questionable, and second, the initial $\mathrm{k}$ values are not very different in any event. Thus, for this industry, we observe that own price and scale cost-minimization gives capital-1abor ratios of 2.45 for Canadian-owned firms and 2.36 for U.S.-owned firms, a difference of less than 5 percent. Applying Canadian levels and factor prices to U.S. technology raises the U.S. $k$ value to 2.47 , for all intents and purposes, the same as the Canadian one. Given the technical problem of this simulation, and the small differences in capital-intensity, this would not appear to be a valid case of similar production technology.

For the other six industries, on the other hand, initial k-ratio differences are substantial, and simulated values do not, in any instance, close more than 12 percent of the gap (Industry 3042, 
where the simulation closes 0.19 of the 1.76 gap). Indeed, for three industries (Confectionary, Commercial Printing, and Major Appliances) the gap between $k_{c}$ and $k_{u}$ opens, implying that technology differences account for more than 100 percent of the actual observed differences in k-ratios, and that the effects of scale and factor prices are to reduce the observed gap, vis-a-vis the true technology gap. In one case, Throwsters and Yarns, no perceptible change occurs under the simulation, which can be interpreted as saying that the entire difference in observed optimal ratios of capital to labor is attributable to differences in technology.

IV. CONCLUSION

Many earlier studies of differences between foreign-owned and Canadian-owned firms have been done and whatever their conclusions on the desirability of foreign investment, most contribute to the conventional wisdom that foreign-owned (usually U.S.-owned) firms, are larger, more capital intensive, have higher labor productivity, and have lower costs of production. This is often stated in capsule form as saying they are more "efficient." Using the translog production function, we estimate for seven four-digit industries in Canada, separate production function for U.S. owned and Canadian-owned firms, and find evidence to dispute several of these views.

While it does appear clear that U.S.-owned firms are larger, it is less clear that they are more capital-intensive, only four of seven industries exhibiting this characteristic. Given our limited coverage, this conclusion is, of course, open to doubt. However, the results for other characteristics do show more strongly that the 
conventional wisdom cannot be simply accepted. U.S.-owned firms are by no means consistently lower cost producers (as measured by marginal cost) nor do they consistently have a higher marginal product of labor.

Further, in the four clear cases of industries where U.S. firms use higher capital-labor ratios, some of this difference is found to be reduced by accounting for differences in scale and factor prices, though in some cases the difference is in fact increased. The sum effect of controlling for scale and factor prices is to show that, in four of seven industries, U.S.-owned firms have technologies with higher capital-intensity in one, equal in four, and lower in two. The most important implication of this is that while there are differences in the technology of U.S.-owned and Canadian firms, it is not necessarily the U.S.-owned firms which have more capital-intensive technologies. For some industries it is in fact the Canadian firms that operate with the more capital-intensive technology. One last conclusion is coincidentally reached: we find no evidence in our analysis for the Globerman hypothesis that "technological spillover" occurs within an industry from U.S.-owned to Canadian-owned firms.

To conclude, then, the simulation analysis strongly supports the position that U.S.-owned firms and Canadian-owned firms operate with different technologies. It is perhaps these differences, rather than some notion of "efficiency," that underlie much of the conventional findings about larger scale, more productive labor, higher capital intensity, and lower unit costs. Indeed, we have not 
found strong support for any of these commonly noted hypotheses once all production factors are fully incorporated into a trans-log production function. We suspect this is not a random result attributable to the limited sample in our analysis, rather, it reflects the erroneous partial definitions of productivity and costs used in earlier studies, most of which necessarily relied on averages, partial productivity measures, and single observations of a variable which reflects a variety of economic phenomena. The production function analysis has permitted a clean-cut distinction of various influences, allowing one to calculate efficiency marginal costs, ceteris-paribus productivities of labor rather than the catch-all mutatis-mutandis value generally used, and to isolate the existence of technology differences separately from the effects of scale and factor prices. 33 We conclude that the only clear-cut distinctions between U.S.-owned and Canadian-owned firms are the scale of production, and differences in production technology.

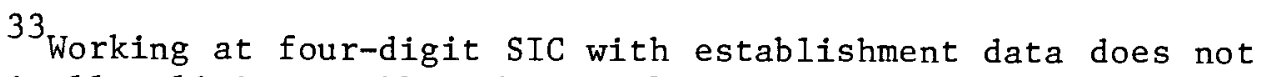
automatically eliminate all problems of product-line differences, but it clearly goes much farther in this respect than other studies have done. Short of a far more massive effort of product-line production functions--in practice, made impossible by lack of data in Canada or elsewhere we cannot see how much more can be done to account for hetrogeneity in econometric analysis. 